\title{
Efek Model Problem Based Learning Terhadap Kemampuan Pemecahan Masalah Siswasma Negeri 2 Pematangsiantar
}

\author{
Andriono Manalu, S.Pd., M.Pd. \\ Dosen Program Studi Pendidikan Fisika \\ Fakultas Keguruan dan Ilmu Pendidikan Universitas HKBP Nommensen \\ andrifis@ymail.com
}

\begin{abstract}
ABSTRAK
Penelitian ini bertujuan untuk melihat efektivitas model problem based learning (PBL) terhadap kemampuan pemecahan masalah siswa pada materi fluida statis. Populasi penelitian ini siswa kelas X SMA Negeri 2 Pematangsiantar tahun pelajaran 2015/2016. Sampel dalam penelitian ini terdiri dari 2 kelas, yang terdiri dari kelas X-2 sebagai kelas kontrol yang menerapkan pembelajaran konvensional dan kelas X-3 sebagai kelas eksperimen yang menerapkan model pembelajaran berbasis masalah yang masing-masing berjumlah 44 orang. Pengambilan sampel dilakukan dengan metode random (probability sampling). Metode penelitian yang digunakan adalah eksperimen kuasi dengan desain randomized control group pretest-postest. Data kemampuan pemecahan masalah dikumpulkan dengan instrumen tes kemampuan pemecahan masalah dalam bentuk uraian yang telah dinyatakan valid dan reliabel. Efektivitas model pembelajaran dinilai berdasarkan perbandingan rata- rata nilai gain yang dinormalisasi antara kelas eksperimen dan kelas kontrol. Hasil penelitian dapat disimpulkan bahwa penggunaan model problem based learning pada materi fluida statis secara signifikan dapat lebih efektif dalam meningkatkan kemampuan pemecahan masalah siswa dan berada pada kategori tinggi.
\end{abstract}

Kata Kunci : problem based learning dan kemampuan pemecahan masalah

\begin{abstract}
The research purposed to see the effectivity of the application of problem based learning $(P B L)$ model to problem solving ability of fluid statics. The population of this research are all the ten grade students SMA Negeri 2 Pematangsiantar academic year 2015/2016. The research sample of two clasess consist of $X-3$ class as class consit of 44 students applied experimental model of Problem Based Learning and X-2 class as class consist of 44 students applied to conventional learning. The sampling based on random cluster sampling technique. Research method were quasi eksperiment with randomized control group pretest-postest design. The data of problem solving ability with test instruments in the form of descriptions of 4 questions that have been declared valid and reliable. The effectifity of learning model assessed based comparing the average normalized gain value between experiment and control class. The results showed that an application of problem based learning model on fluid statics topics significantly more effective to improve problem solving ability of students and it is high category.
\end{abstract}

Keywords: Problem Based learning and Problem Solving Ability

INTRODUCTION

Pendidikan sains khususnya fisika sebagai bagian dari pendidikan pada umumnya memiliki peran dalam meningkatkan sumber daya manusia yang berkualitas. Peraturan Menteri Pendidikan
Nasional No. 22 tahun 2006 tentang Standar Isi menyebutkan bahwa mata pelajaran fisika di SMA bertujuan agar peserta didik memiliki kemampuan antara lain: (1) meningkatkan keyakinan terhadap kebesaran Tuhan Yang Maha Esa; (2) 
mengembangkan kemampuan bernalar dalam berpikir analisis dengan menggunakan konsep dan prinsip fisika untuk menyelesaian masalah; (3) memupuk sikap ilmiah yang meliputi kejujuran, terbuka, kritis dan dapat bekerjasama dengan orang lain; serta (4) mempunyai keterampilan mengembangkan pengetahuan.

Berdasarkan tujuan tersebut dapat dipahami bahwa melalui pembelajaran fisika di SMA diharapkan siswa tidak hanya menguasai pengetahuan semata tetapi menjadi individu yang mempunyai keterampilan serta mampu mengatasi masalah-masalah yang ditemukan di dalam kehidupan sehari-hari. McDermott (dalam Sani, 2012) mengidentifikasikan sejumlah kemampuan yang dapat dikembangkan dalam pembelajaran fisika, yaitu: (1) kemampuan melakukan penalaran baik kualitatif maupun kuantitatif, (2) kemampuan menginterpretasikan representasi ilmiah seperti gambar, persamaan matematis, dan grafik, (3) keterampilan proses, (4) kemampuan memecahkan masalah, (5) keterampilan komunikasi.

Pembelajaran sains khususnya fisika pada dasarnya berkaitan dengan bagaimana cara mencari tahu tentang alam secara sistematis, sehingga sains bukan hanya penguasaan kumpulan pengetahuan yang berupa fakta, konsep atau prinsip saja tetapi juga merupakan suatu proses penemuan melalui penyelidikan atau percobaan. Khanifiyah (2014) mengatakan bahwa pembelajaran fisika diharapkan dapat mendorong siswa untuk menjadi pembelajar yang aktif dan berpikir kritis dalam menganalisis serta mengaplikasikan konsep untuk memecahkan masalahmasalah yang ditemukan dalam kehidupan sehari-hari.

Salah satu pokok bahasan Fisika di kelas X adalah Fluida Statis yang harus di belajarkan di sekolah. Konsep fluida statis merupakan materi yang sangat berhubungan dan banyak diaplikasikan dalam kehidupan sehari-hari. Berdasarkan pengalaman peneliti, penyampaian materi fluida cenderung dilakukan dengan cara ceramah dan membaca literatur, siswa hanya diajarkan menghafal konsep, prinsip, hukum dan rumus-rumus, pemahaman yang di miliki siswa kurang memiliki kebermaknaan yang dapat diaplikasikan dalam kehidupan sehari-hari terlebih dalam penyelesaian masalah yang berhubungan dengan materi fluida statis

Berdasarkan studi pendahuluan yang dilakukan oleh peneliti pada salah satu kelas $X$ SMA Negeri 2 Pematangsiantar untuk melihat kemampuan pemecahan masalah peneliti memberikan soal berupa pertanyaan uraian kemampuan pemecahan masalah, dengan rubrik penilaiannya berdasarkan kemampuam pemecahan masalah. Diperoleh data hanya sekitar 23\% sampai pada tahap penerapan strategi pemecahan masalah dan $77 \%$ lagi sampai pada tahap strategi pemecahan masalah. Berdasarkan fakta dari kegiatan observasi awal tersebut dapat disimpulkan bahwa kemampuan pemecahan masalah di sekolah tersebut masih rendah.

Kesimpulan tersebut diperkuat oleh pernyataan melalui hasil wawancara dengan salah satu guru fisika SMA Negeri 2 Pematangsiantar, mengatakan bahwa pembelajaran fisika diajarkan dengan model konvensional yang terdiri dari metode demonstrasi dan presentase. Guru cenderung memindahkan pengetahuan yang dimiliki kepikiran siswa, mengajarkan secara urut halaman per halaman tanpa membahas keterkaitan antara konsepkonsep atau masalah, mementingkan hasil dari pada proses. Siswa mejadi pasif dan kurang terlibat dalam proses belajar mengajar.

Menanggapi permasalahan di atas perlu adanya model yang mengorientasikan pembelajaran pada masalah-masalah nyata yang dapat menciptakan keterlibatan siswa dalam proses belajar mengajar untuk menumbuhkan kemampuan memecahkan masalah siswa. Membiasakan bekerja ilmiah diharapkan dapat menumbuhkan kebiasaan berpikir dan bertindak yang 
merefleksikan penguasaan pengetahuan, keterampilan dan sikap ilmiah yang dimiliki siswa, sehingga dengan sendirinya model pembelajaran itu akan berakibat pada meningkatnya pengetahuan, keterampilan dan sikap ilmiah siswa sebagai hasil belajar.

Menurut Arends (2008) model pembelajaran berbasis masalah (problem based learning) merupakan model pembelajaran yang mengorgansisasikan pembelajaran di sekitar pertanyaan dan masalah, melalui pengajuan situasi kehidupan nyata yang otentik dan bermakna, yang mendorong siswa untuk melakukan proses penyelidikan dan inkuri, dengan menghindari jawaban sederhana, serta memungkinkan adanya berbagai macam solusi dari situasi tersebut. Dalam pembelajaran berdasarkan masalah keaktifan siswa lebih diutamakan karena kegiatan dalam pembelajaran berdasarkan masalah meliputi analisis terhadap masalah, merumuskan hipotesis, perencanakan penelitian sampai pelaksanannya, hingga mendapatkan sebuah kesimpulan yang merupakan jawaban atau pemecahan permasalahan yang diberikan.

PBL tidak dirancang untuk membantu guru memberikan informasi sebanyak-banyaknya kepada siswa. Tujuan pembelajaran berbasis masalah untuk membantu siswa mengembangkan kemampuan berpikir dan pemecahan masalah, belajar berbagai peran orang dewasa melalui pelibatan mereka dalam pengalaman nyata, menjadi pebelajar yang otonom dan mandiri. PBL melibatkan siswa dalam penyelidikan pilihan sendiri, yang memungkinkan siswa menginterpretasikan dan menjelaskan fenomena dunia nyata (Arends, 2008)

Beberapa penelitian telah menunjukkan dampak positif dari implementai model pembelajaran berbasis masalah. Hasil penelitian Khanifiyah (2014) menyimpulkan bahwa model pembelajaran berdasarkan masalah sangat efektip untuk meningkatkan kemampuan menganalisis dan memecahkan masalah fisika. Dwi, dkk. (2014) menyimpulkan bahwa model permbelajaran berdasarkan masalah dapat menumbuhkan keterampilan proses sains sekaligus meningkatkan kemampuan pemecahan masalah siswa, yang berarti model pembelajaran berbasis masalah merupakan model pembelajaran yang efektif digunakan, khususnya untuk meningkatkan kemampuan memecahkan masalah.

Selama dalam prosesnya, pada hakikatnya PBL menekankan penemuan solusi baru dari suatu permasalahan nyata yang secara tidak langsung telah mengajak siswa untuk kreatif, inovatif dan memiliki daya cipta. Pembelajaran ini mencirikan student centered, guru sebagai fasilitator, pengarah dan sistem kolaboratif, siswa mengkonstruksi pengetahuan sendiri dan mengembangkan kompetensi daya cipta siswa secara aktual. Dengan demikian, diharapkan kompetensi-kompetensi yang dituntut dalam kurikulum khususnya dalam pemecahan masalah dapat dikembangkan dengan baik.

Telah dilakukan penelitian tentang penerapan model PBL pada pokok bahasan fluida statis untuk yang bertujuan untuk melihat efektifitas model PBL dalam mengembangkan kemampuan pemecahan masalah siswa SMA. Efektivitas model pembelajaran yang diuji ditentukan berdasarkan perbandingan rata-rata skor gain yang dinormalisasi, $\mathrm{N}$-gain dengan model pembanding.

\section{METODE PENELITIAN}

Penelitian ini dilakukan di SMA Negeri 2 Pematangsiantar, pada semester genap Tahun Pelajaran 2015/2016. Populasi dalam penelitian ini adalah seluruh siswa kelas X SMA Negeri 2 Pematangsiantar. Sampel dalam penelitian ini terdiri dari 2 kelas, yang terdiri dari kelas X-2 sebagai kelas kontrol yang menerapkan model pembelajaran konvensional dan kelas X-3 sebagai kelas eksperimen menerapkan model pembelajaran berbasis masalah yang masing-masing terdiri 44 orang. Instrumen 
tes kemampuan pemecahan masalah dalam bentuk uraian sebanyak 4 soal yang telah dinyatakan valid dan reliabel. Tes kemampuan pemecahan masalah (KPM) mencakup lima tahap yaitu (1) visualize the problem. Pada langkah ini, dilakukan visualisasi permasalahan dari kata-kata menjadi representasi visual, membuat daftar variabel yang diketahui dan tidak diketahui, dan identifikasi konsep dasar. (2) describe the problem in physics description. Pada langkah ini, representasi visual diubah menjadi deskripsi fisika dengan membuat diagram benda bebas dan memilih sistem koordinat. (3) plan the solution, yaitu merencanakan solusi dengan cara mengubah deskripsi fisika menjadi representasi hubungan sebab akibat, deduksi induksi. (4) execute the plan, melaksanakan rencana melalui kajian analitis atau eksperimen. (5) check and evaluate, mengevaluasi solusi yang didapatkan mengecek/membandingkan kelengkapan jawaban dengan referensi tertentu atau penelitian terdahulu (Heller \& Heller, 1991).

Penelitian ini menggunakan metode eksperimen kuasi dengan desain randomized control group pretest-postest (Frankel \& Wallen, 1993). Dengan desain ini, mula-mula terhadap kedua kelompok dilakukan tes awal, kemudian kedua kelompok diberikan perlakuan pembelajaran yang berbeda dan setelah itu dilakukan tes akhir. Desain penelitian selengkapnya disajikan pada Tabel 1 .

Tabel 1. Desain Penelitian Tipe Control Group Pretest-Postest

\begin{tabular}{|c|c|c|c|}
\hline Kelas & $\begin{array}{c}\text { Tes } \\
\text { Awal }\end{array}$ & Perlakuan & $\begin{array}{c}\text { Tes } \\
\text { Akhir }\end{array}$ \\
\hline Eksperimen & $\mathrm{T}_{1}$ & $\mathrm{X}_{1}$ & $\mathrm{~T}_{2}$ \\
\hline Kontrol & $\mathrm{T}_{1}$ & $\mathrm{X}_{2}$ & $\mathrm{~T}_{2}$ \\
\hline
\end{tabular}

Keterangan :

$\mathrm{T}_{1}=$ Tes awal yang diberikan pada kelas eksperimen dan kelas kontrol sebelum perlakuan

$\mathrm{T}_{2}=$ Tes akhir yang diberikan pada kelas eksperimen dan kelas kontrol setelah perlakuan

$\mathrm{X}_{1} \quad=$ Perlakuan pada kelas eksperimen yaitu penerapan pengajaran problem based learning

$\mathrm{X}_{2}=$ Perlakuan pada kelas kontrol yaitu penerapan pembelajaran konvensional

Efektivitas penggunaan model PBL ditentukan berdasarkan perbandingan $\mathrm{N}$ gain kemampuan pemecahan masalah yang diperoleh kelas eksperimen dengan yang diperoleh kelas kontrol. Suatu pembelajaran dikatakan lebih efektif jika menghasilkan $\mathrm{N}$-gain kemampuan pemecahan masalah lebih tinggi dibanding pembelajaran lainnya. Gain yang dinormalisasi digunakan rumus yang dikembangkan oleh Meltzer (2002), yaitu :

dengang $\mathrm{N}$-gain adalah gain yang dinormalisasi, $S_{\max }$ adalah skor maksimum (ideal), $S_{\text {post }}$ adalah skor tes akhir, sedangkan $S_{\text {pre }}$ adalah skor tes awal. Tinggi rendahnya gain yang dinormalisasi dapat diklasifikasikan sebagai berikut: (1) jika $g$ $>0,7$, maka $\mathrm{N}$-gain yang dihasilkan kategori tinggi; (2) jika 0,30,7, maka $\mathrm{N}$ gain yang dihasilkan dalam kategori sedang; dan jika g <0,3, maka $\mathrm{N}$-gain yang dihasilkan berada pada kategori rendah

Fase-fase model PBL yang digunakan dalam penelitian ini adalah fase PBL yang di kembangkan oleh Arends (2008) yang terdiri dari lima sintaks, sebagaimana yang disajikan dalam Tabel 2 .

Tabel 2. Sintaks Model Problem Based Learning menurut Arends (2008)

\begin{tabular}{|l|l|}
\hline Fase & Perilaku Guru \\
\hline $\begin{array}{l}\text { Fase 1: } \\
\text { Mengorientasikan siswa } \\
\text { kepada masalah. }\end{array}$ & $\begin{array}{l}\text { Guru menginformasikan tujuan-tujuan pembelajaran, } \\
\text { mendeskripsikan kebutuhan-kebutuhan logistik penting dan } \\
\text { memotivasi siswa agar terlibat dalam kegiatan pemecahan } \\
\text { masalah yang mereka pilih sendiri. }\end{array}$ \\
\hline
\end{tabular}




\begin{tabular}{|l|l|}
\hline Fase & Perilaku Guru \\
\hline $\begin{array}{l}\text { Fase 2: } \\
\text { Mengorganisasikan siswa } \\
\text { untuk belajar. }\end{array}$ & $\begin{array}{l}\text { Guru membantu siswa menentukan dan mengatur tugas-tugas } \\
\text { belajar yang berhubungan dengan masalah itu. }\end{array}$ \\
\hline $\begin{array}{l}\text { Fase 3: } \\
\text { Membantu penyelidikan } \\
\text { mandiri dan kelompok. }\end{array}$ & $\begin{array}{l}\text { Guru mendorong siswa mengumpulkan informasi yang sesuai, } \\
\text { melaksanakan eksperimen, mencari penjelasan, dan solusi. }\end{array}$ \\
\hline $\begin{array}{l}\text { Fase 4: } \\
\text { Mengembangkan dan } \\
\text { menyajikan hasil karya serta }\end{array}$ & $\begin{array}{l}\text { Guru membantu siswa dalam merencanakan dan menyiapkan } \\
\text { hasil karya yang sesuai seperti laporan, rekaman video, dan } \\
\text { model, serta membantu mereka berbagi karya mereka. }\end{array}$ \\
\hline $\begin{array}{l}\text { Fase 5: } \\
\begin{array}{l}\text { Menganalisis dan } \\
\text { mengevaluasi proses } \\
\text { pemecahan masalah. }\end{array}\end{array}$ & $\begin{array}{l}\text { Guru membantu siswa melakukan refleksi atas penyelidikan } \\
\text { dan proses-proses yang mereka gunakan. }\end{array}$ \\
\hline
\end{tabular}

\section{HASIL PENELITIAN}

Berdasarkan hasil tes awal diperoleh bahwa kelas eksperimen dan kelas kontrol berdistribusi normal dan homogen. Rerata tes awal kelas eksperimen 34,14 dan rerata tes awal kelas kontrol adalah 34,27. Berdasarkan data tes awal dengan menggunakan uji hipotesis dengan uji beda (Uji-t) menunjukkan bahwa siswa kelas eksperimen dan kontrol memiliki tingkat kemampuan yang hampir sama. Perhitungan normalitas, homogenitas dan uji- $t$ untuk dua sampel bebas (independent sample t-test) menggunakan SPSS 16.0.

Pengujian efektivitas model PBL dalam meningkatkan kemampuan pemecahan masalah siswa dinyatakan dengan \% N-gain pada topik Fluida Statis. Signifikansi perbedaan $\% \quad \mathrm{~N}$-gain kemampuan pemecahan masalah antara kedua kelompok menggunakan uji-t. Hasil uji normalitas, uji homogenitas dan uji beda dua rerata \% $\mathrm{N}$-gain pada kelompok eksperimen dan kontrol ditunjukkan pada Tabel 3. Berdasarkan Tabel 3 tampak bahwa \% N-gain kemampuan pemecahan masalah, baik pada kelas eksperimen dan kelas kontrol berdistribusi normal dan variansnya homogen, maka signifikansi perbedaan $\% \mathrm{~N}$-gain peningkatan kemampuan pemecahan masalah antara kedua kelompok menggunakan uji beda (Uji-t).

Tabel 3. Hasil Uji Normalitas, Homogenitas dan Uji beda dua rerata $\% \mathrm{~N}$-gain Kemampuan Pemecahan Masalah Siswa yang diperoleh Kelompok Eksperimen dan Kontrol.

\begin{tabular}{|c|c|c|c|c|c|c|c|c|c|}
\hline \multicolumn{4}{|c|}{ Kelompok Eksperimen } & \multicolumn{4}{|c|}{ Kelompok Kontrol } & $\begin{array}{l}\text { Varians } \% \\
\end{array}$ & $\overline{\mathbf{P}}$ \\
\hline $\begin{array}{l}\text { Rerata } \\
\text { Tes } \\
\text { Awal }\end{array}$ & $\begin{array}{l}\text { Rerata } \\
\text { Tes } \\
\text { Akhir }\end{array}$ & $\begin{array}{l}\mathrm{N}- \\
\text { gain } \\
(\%)\end{array}$ & $\begin{array}{l}\text { Distribusi } \\
\% \quad \text { N-gain } \\
\text { Eksperimen }\end{array}$ & $\begin{array}{l}\text { Rerata } \\
\text { Tes } \\
\text { Awal }\end{array}$ & $\begin{array}{l}\text { Rerata } \\
\text { Tes } \\
\text { Akhir }\end{array}$ & $\begin{array}{l}\mathrm{N}- \\
\text { gain } \\
(\%)\end{array}$ & $\begin{array}{l}\text { Distribusi } \\
\% \quad \text { N-gain } \\
\text { Kontrol }\end{array}$ & & \\
\hline 34,14 & 82,95 & 74,1 & Normal & 34,27 & 71,27 & 56,3 & Normal & Homogen & $\begin{array}{l}0,000 \\
\text { (signifikan) }\end{array}$ \\
\hline
\end{tabular}

Keterangan : Skor maksimum 10 
Berdasarkan Tabel 3 dapat diketahui bahwa $\% \mathrm{~N}$-gain kemampuan pemecahan masalah yang dicapai kelompok eksperimen sebesar $74,1 \%$, termasuk kategori tinggi, sedangkan yang dicapai kelompok kontrol sebesar 56,3 \%, termasuk dalam kategori sedang. Rerata N-gain kemampuan pemecahan masalah untuk kelas eksperimen lebih besar daripada rerata $\mathrm{N}$ gain kemampuan pemecahan masalah kelas kontrol.

Rerata kemampuan pemecahan masalah siswa dapat di jabarkan pada setiap langkah kemampuan pemecahan masalah antar kelompok eksperimen dan kelompok kontrol seperti ditunjukkan pada gambar 1 .

Gambar 1 Perbandingan Rerata untuk Setiap Langkah Kemampuan Pemecahan Masalah antara Kelas Eksperimen dan kontrol. 1. Visualize the problem. 2. Describe the problem in physics description. 3. Plan the solution. 4. Execute the plan. 5. Check and evaluate

Berdasarkan hasil analisis rerata dari setiap langkah kemampuan pemecahan masalah seperti yang ditunjukkan Gambar 1 diperolah pada tahap memahami masalah. menginterpretasi, merancang penyelesaian, melaksanakan pemecahan, dan evaluasi solusi yang dibelajarkan dengan model pembelajaran berbasis masalah dan konvensional memiliki hasil yang berbedabeda.

Pertama, pada tahap memahami (visualize the problem) kelas ekperimen diperoleh rerata 6,68 sedangkan pada kelas kontrol 4,70. Pada langkah ini, dilakukan visualisasi permasalahan dari kata-kata menjadi representasi visual, membuat daftar variabel yang diketahui dan tidak diketahui, identifikasi konsep dasar. Siswa yang dibelajarkan dengan PBL lebih mudah memahami dengan memadukan kemampuan konsep awal siswa melalui perumusan masalah untuk dikembangkan kearah masalah yang sebenarnya dengan berbagai pemahaman yang berbeda dan mengarah pada jawaban yang bervariasi. Berbeda dengan siswa yang diajar dengan model konvensional dimana interaksi pembelajaran cenderung satu arah dari guru ke siswa sehingga inisiatif siswa dalam memahami hal baru di luar dari apa yang disajikan guru menjadi sulit untuk dikembangkan.

Kedua, pada tahap menginterpretasikan masalah (describe the problem in physics description) kelas ekperimen diperoleh rerata 6,52 sedangkan pada kelas kontrol 6,11. Pada langkah ini, representasi visual diubah menjadi deskripsi fisika dengan membuat diagram benda bebas dan memilih sistem koordinat, atau membuat sketsa. Siswa yang dibelajarkan dengan PBL lebih mudah menginterpretasikan masalah dengan membuat sketsa diagram sehingga mengarahkan masalah kepada konsep fisika lebih cepat karena dalam pembelajaran PBL telah dibiasakan terorientasi terhadap masalah. Berbeda dengan siswa yang diajar dengan model konvensional dimana kemampuan untuk menginterpretasi masalah tidak dibiasakan selama proses pembelajaran berlangsung.

Ketiga, pada tahap merencanakan penyelesaian masalah (plan the solution), kelas ekperimen diperoleh rerata 6,70 sedangkan pada kelas kontrol 5,45. Tahap ini merencanakan solusi dengan cara mengubah deskripsi fisika menjadi representasi matematis. Dalam pembelajaran PBL pada tahap penyelidikan dimana siswa telah dibiasakan memperoleh data autentik kemudian siswa mengolah data. Kegiatan ini akan membiasakan siswa untuk membuat perencanaan yang matang yaitu penyelidikan dimulai dari mana dan berakhir dimana. Berbeda dengan siswa yang diajar dengan model konvensional dimana kemampuan merencanakan lebih 
abstrak tampa penyuguhan penyelidikan autentik

Keempat, pada tahap melaksanakan penyelesaian masalah (execute the plan), melaksanakan rencana dengan melakukan operasi matematis. Kegiatan ini dilakukan untuk mengolah data dari hasil penyelidikan melalui persamaan matematis melalui konsep fisika. Kelas ekperimen diperoleh rerata 6,55 sedangkan pada kelas kontrol 6,00

Kelima, pada tahap mengevaluasi solusi (check and evaluate) kelas ekperimen diperoleh rerata 6,61 sedangkan pada kelas kontrol 6,43. Mengevaluasi solusi yang didapatkan dengan mengecek kelengkapan jawaban, tanda, satuan dan nilai dengan membandingkan atau menyesuaikan jawaban yang diperoleh terhadap konsep fisika antara lain dengan cara menyesuaikan jawaban dengan konstanta, azas, hukum, teori dan ketentuan umum yang telah di peroleh melalui penelitian sebelumnya.

Langkah-langkah kemampuan pemecahan masalah dengan metode Heller \& Heller (1991) merupakan serangkaian kegiatan yang sistematis terintegrasi mulai dari awal sampai akhir. Jika pada tahap awal tidak dapat berjalan dengan baik maka otomatis pada tahap berikutnya akan menuai kesulitan. Hal inilah yang membedakan kemampuan pemecahan masalah yang dibelajarkan dengan PBL dengan konvensional.

Model pembelajaran PBLadalah upaya pengembangan para pembelajar yang mandiri, metodenya mensyaratkan partisipasi aktif siswa dalam kegiatan penyelesaian masalah. Siswa sebenarnya memiliki rasa ingin tahu dan hasrat yang besar untuk tumbuh berkembang. Model pembelajaran PBL memanfaatkan eksplorasi kegairahan alami siswa, memberikan siswa arahan-arahan khusus sehingga siswa dapat mengeksplorasi bidang-bidang baru secara efektif.

Arends (2008) mengatakan, PBL mengambil psikologi kognitif sebagai dukungan teoritisnya. Fokusnya tidak banyak pada apa yang sedang dikerjakan siswa (perilaku), tetapi pada apa yang mereka pikirkan (kognisi) selama mereka mengajarkannya.Peran guru dalam pembelajaran berbasis masalah adalah sebagai pembimbing dan fasilitator sehingga siswa dapat belajar untuk berpikir dan menyelesaikan masalahnya sendiri.

Model pembelajaran PBL dirancang untuk meningkatkan kemampuan berfikir siswa. Prosedur dirancang untuk memfasilitasi usaha guru dan siswa yang berkaitan erat dengan unsur-unsur materi pokok dan uraian materi agar dapat menghasilkan siswa-siswa yang mandiri. Siswa dapat mengkontruksikan pengetahuannya yang didasari oleh 5 langkah dalam , yaitu : (1) mengorientasikan masalah, (2) mengorganisai siswa dalam kelompok belajar, (3) membantu siswa secara individual atau kelompok dalam melaksanakan penelitian, (4) mengembangkan dan menyajikan hasil karya dan (5) analisis dan evaluasi proses pemecahan masalah.

Kesimpulan di atas senada dengan hasil penelitian sebelumnya. Khanifiah (2014) mengatakan problem based lerning mampu mengembangkan kemampuan pemecahan masalah dan meningkatkan pemahaman konsep, sikap dan ketertarikan siswa belajar fisika. Pada penelitian ini kemampuan pemecahan masalah menggunakan indikator analisis kualitatif dan pengertian situasi problematik, merumuskan hipotesis, strategi elaborasi, memecahkan masalah serta analisis hasil. Setiap indikator diamati selama pembelajaran dan dilihat perkembangannya, tidak dilakukan tes seperti pada penelitian diatas sehingga sulit menentukan signifikansi perngaruh dari model pembelajaran itu sendiri. Nasrodin (2013) mengtakan model PBL dapat meningkatkan hasil belajar melalui keterampilan proses sains yang berlangsung, siswa mampu memecahkan permasalah otentik selama pembelajaran. Hal berbeda dengan penelitian ini dimana 
keterampilan proses sains dan kemampuan pemecahan masalah hanya diamati untuk dilihat peningkatannya, namun apakah kedua variabel tersebut signifikan berbeda tidak dijelaskan dalam penelitian ini.

DAFTAR PUSTAKA

Arends, R. I. (2008). Learning to Teach. Seven Editions. New York: McGraw-Hill.

Dwi, I. M., Arif, H., dan Sentot, K. (2013). Pengaruh Strategi Problem Based Learning Berbasis ICT terhadap Pemahaman Konsep dan Kemampuan Pemecahan Masalah Fisika. Jurnal Pendidikan Fisika Indonesia, 9 : 8-17.

Fraenkel, J. R. \& Wallen, N. E., (1993). How to design and Evaluate Researchin Education. Second Edition. New York: McGraw-Hill book Co.

Heller \& Heller. (1991). Teaching Problem Solving through Cooperative Grouping. Part 1: Group Versus Individuals Problem Solving. Am. J. Phys. 60, 627-636.
Khanifiyah (2014). Efektivitas Model Pembelajaran Problem Based Intruction Berbantuan Media Audio-Visual dalam Meningkatkan Kemampuan Menganalisis dan Memecahkan Masalah Fisika.Unnes Physics Education Jurnal.

Meltzer, D. E. (2002). "The Relationshif between Mathematics Preparation and Conceptual Learning Gain in Physics: A Possible Hidden Variable Score". Am. J. Phys. 70, (2), 1259-1267

Nasrodin, Hindarto, N., dan Supeni, S. (2013). Analisis Kebiasaan Bekerja Ilmiah Mahasiswa Fisika pada Pembelajaran Mata Kuliah Praktikum Fisika Dasar. Unnes Physics Education Journal, 2 (1) : 84-91. Tersedia http://journal.unnes.ac.id/sju/index. php/upej [27 Nopember 2013]

Permendiknas Nomor 22 Tahun 2006. Standar Isi Mata Pelajaran Fisika.

Sani, R. A., (2013). Pembelajaran Saintifik untuk Implementasi Kurikulum 2013. Jakarta: PT. Bumi Aksara. 